\title{
Barbara Czarniawaska: Organizational Change - Fashions, Institutions, and Translations
}

\author{
Hervé Corvellec and Ulla Eriksson-Zetterquist
}

\begin{abstract}
Combining neo-institutionalism, actor network theory, and Gabriel Tarde's sociology, Czarniawska considers the key driver of organizational change to be imitation but an imitation that rests on translation. Organizations emulate one another by translating fashionable ideas according to their understanding, traditions, needs, and means. As translation in this tradition always entails a transformation of the translated idea or object, unexpected consequences will be expected. She does not consider these consequences to be necessarily negative; however, because if stabilized and institutionalized, unintended change can turn out to be as positive as planned change. A further strength of Czarniawska's is her ability to provide methodological tools that follow the translation processes for change: organizational ethnographies, narrative methodology, and shadowing.
\end{abstract}

\section{Keywords}

Institutionalism • Imitation • Fashion • Translation • Action net • Ethnography • Narrative $\cdot$ Shadowing

H. Corvellec $(\bowtie)$

Department of Service Studies, Lund University, Helsingborg, Sweden

Gothenburg Research Institute (GRI), University of Gothenburg, Gothenburg, Sweden

e-mail: herve.corvellec@ism.lu.se

U. Eriksson-Zetterquist

Gothenburg Research Institute (GRI), University of Gothenburg, Gothenburg, Sweden

Weatherhead Center for International Affairs, Harvard University, Cambridge, MA, USA

e-mail: uez@gri.gu.se

D.B. Szabla et al. (eds.), The Palgrave Handbook of Organizational Change Thinkers,

DOI 10.1007/978-3-319-52878-6_72 


\section{Contents}

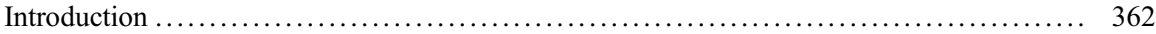

Influences and Motivations: Her Mother's Daughter ........................... 362

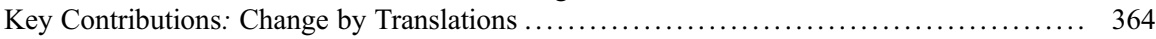

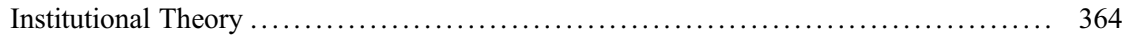

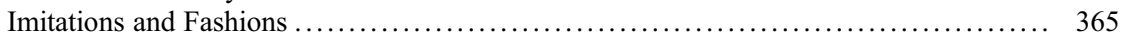

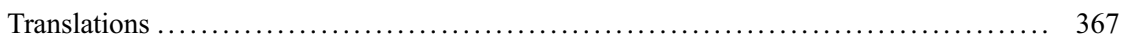

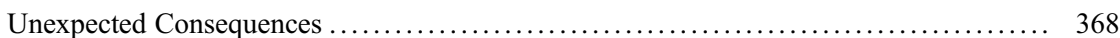

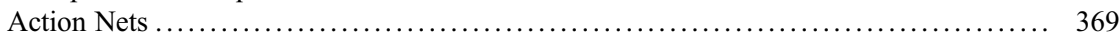

New Insights: Processual Methodologies .................................... 370

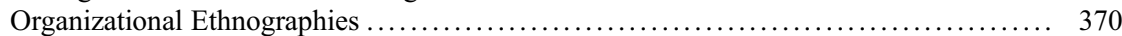

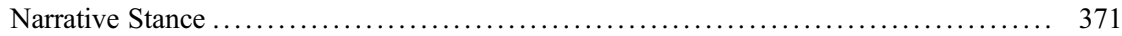

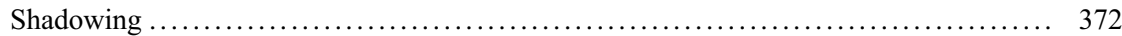

Legacies and Unfinished Business: Unusual Study Object $\ldots \ldots \ldots \ldots \ldots \ldots \ldots \ldots \ldots \ldots \ldots \ldots \ldots \ldots$

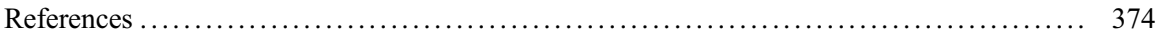

"Se vogliamo che tutto rimanga com'è bisogna che tutto cambi."

Giuseppe Tomasi di Lampedusa

Il gattopardo

\section{Introduction}

"If we want things to stay as they are, things will have to change." This enigmatic assertion by young Tancredi Falconeri, opportunistically rallying behind Garibaldi's Republicans, was made to his aging, aristocratic, and royalist uncle, Don Fabrizio Salina, in Lampedusa's (1960) novel, The Leopard could serve to introduce Barbara Czarniawska's approach to change on three accounts. First, Tancredi's statement suggests approaching change through its effects rather than its nature, particularly because the effects of change can be paradoxical. Second, an interest in change can be a commitment to continuity. Across her career, Barbara Czarniawska has changed objects of interest, theoretical focus, countries, and languages of work, but her main interest has remained the same: "how people are managing and organizing, but in different contexts" (Czarniawska, 2016, On change/interviewer: H. Corvellec, personal communication [unpublished]). Third, this reference to Lampedusa does homage to Czarniawska's encompassing interest for narratives, to which we return.

\section{Influences and Motivations: Her Mother's Daughter}

Born in 1948 in Bialystok, Poland, Barbara considers herself her mother's daughter; having cultivated an early taste for languages, she is now fluent in Polish, English, Swedish, and Italian and can read French. She also developed an interest in travel, literature, and writing. By the beginning of 2016, she had authored 33 books, 108 peer-reviewed articles, 88 chapters, 20 encyclopedia and handbook entries, 
numerous commentaries and popularizing texts, and 25 edited books and special journal issues.

Czarniawska (2004b) has claimed that her early interest in the study of work led her to pursue a master's degree in social psychology at the University of Warsaw in 1970, followed in 1976 by a Ph.D. in economic sciences at the Central School of Planning and Statistics in Warsaw. After a year at the MIT Sloan School of Management on a grant from the American Council of Learned Societies, she spent a year at Wissenschaftszentrum Berlin für Sozialforschung (Berlin Social Science Center), in what was then West Berlin. She later moved to Sweden at the invitation of Arbetslivscentrum (Swedish Center for Working Life), then took a position at the Stockholm School of Economics, assumed the chair in management at Lund University, and finally moved to the School of Business, Economics and Law at the University of Gothenburg where she has since held a chair as Professor of Management Studies and participated in developing the Gothenburg Research Institute (GRI). She is a member of the Royal Swedish Academy of Sciences, the Royal Swedish Academy of Engineering Sciences, and the Finnish Society of Sciences and Letters and is an honorary fellow of the European Institute of Advanced Studies in Brussels. And she has not only led 35 doctoral students to completion, including the two authors of this text, she shows an all-encompassing interest in meeting young researchers and helping them to connect with one another through her networks.

A scholar in feminist theory on organizing (see, for example, Czarniawska 2004c), Czarniawska has developed an acute perception of what it means to be a female immigrant from an Eastern European country, both for herself and for others. And together with female academics in a variety of fields who gather in her extended personal networks, she personifies the possibility and necessity of a more genderequal academic community.

Czarniawska (2004b) has credited Nils Brunsson, who had written a dissertation on the propensity for change (1976; see also: 1985) for awakening her interest in organizational change. She became particularly interested in Brunsson's observations and those of Johan P. Olsen (1990, 1993): that reforming - an expression for planned change - is the steady state of affairs in public sectors in Sweden, Norway, and Denmark. As reforms do not usually achieve what they are planned to accomplish, a new reform is called for, creating a state of continuous reforming. She rapidly articulated this insight with a neo-institutional theory in organization theory (Czarniawska 2008a; Powell and DiMaggio 1991) and actor-network theory (Latour 1987, 1996). She developed all of this into a theory of action nets (2004d, 2010), to develop an explanation of change as a process that combines fluid and solidified relationships within and among organizations.

To indicate the breadth of her sources of inspiration, no fewer than five deserve mention. First, Albert O. Hirschman (1991), with his idea that practically no planned change reaches its goals, but that the unexpected and unplanned effects of changes are sometimes better and more interesting than the planned ones. The people who are managing the change, however, often do not realize this, focused as they on their own plans and goals. Second was Nicklas Luhman's (1995) view that no system can 
change itself, other than by mistake - by a sort of accidental mutation. Even if organizations are open systems in a physical sense, they are closed systems that keep reproducing themselves. So whatever change happens either does so by mistake or by the wrong repetition.

A third source of influence has been Michel Serres's (1982) idea of translation as used by the likes of Michel Callon (1986) and Bruno Latour (1987). The idea of translation makes it possible to explain how change processes that look alike and may even have the same name move across sectors and countries find and invent new contexts in which to take root, produce a variety of foreseeable and unforeseeable results, and eventually become fashionable managerial recipes. Two volumes that Czarniawska edited with Guje Sevón focus on translation: Translating Organizational Change (1996) and Global Ideas: How Ideas, Objects and Practices Travel in the Global Economy (2005).

Fourth, Czarniawska (2008b) shared with Latour (2002) a renewed interest in the sociology of Gabriel Tarde, a French sociologist from the second half of the nineteenth century. She was particularly interested in the centrality that Tarde gave to imitation and fashion, in order to explain the circulation of ideas, action patterns, and objects - among them, change. Fifth, her interest in narrative as an object of study and a methodological stance (e.g., Bruner 1986) is still an influential source of inspiration. For her, plots, as they combine causality and temporality, offer a way to understand what Karl E. Weick (1979) called the social psychology of organizing: the rationale of changes as actors account their experiences.

\section{Key Contributions: Change by Translations}

Czarniawska's contributions to an enhanced understanding of change are of two related types: theory and methodology. In this section, we examine her theoretical contributions. We first render her brand of institutionalism, then examine the reasons why imitation and fashion drive change, how translations work, and why people may welcome unexpected consequences of change. Finally, we introduce the notion of action net, which describes how organizations are born and evolve.

\section{Institutional Theory}

The starting point of Czarniawska's views on change is institutional theory, particularly popular among Scandinavian organization scholars with an interest in public organizations, as presented by Meyer and Rowan (1977), March and Olsen (1989), and Powell and DiMaggio (1991), among others. Institutional theory comes in many versions. Political scientists tend to use the term institutions as a direct synonym for organizations. Sociologists, anthropologists, and organizational scholars tend to stress the way institutions form social action, are self-reproducing, and are underpinned by social norms (Jepperson 1991). And it is not uncommon that 
different definitions are applied in the same text. It is critical, therefore, to clarify the term used.

Being among the first organizational scholars to stress this point, Czarniawska (1997, p. 43) defined an institution as "a pattern of social action strengthened by a corresponding social norm" (p. 43) - a definition similar to that later phrased by the editors of The SAGE Handbook of Organizational Institutionalism (Greenwood et al. 2008). Referring to Berger and Luckmann's (1966, p. 72) claim that "institutions posit that actions of type X will be performed by actors of type X," she stressed that a constructive reciprocity is assumed, that performance of an X type of action leads to the perception that a given actor belongs to (or aspires to) type $\mathrm{X}$, and vice versa. Just that, within an institutional order, the actors are often not people but "legitimized social groupings": work units, profit centers, departments, corporations, public administration organizations, associations of organizations, and all those whose interactions "constitute a recognized area of institutional life" (Czarniawska 2009, p. 423). But for individual and collective actors alike, an institutional order limits what it is possible to do, think, and imagine. Institutional orders such as church, marriage, and market control and condition at any given time and place what is possible and appropriate change and how it can be undertaken.

A key contribution of institutionalism is the demonstration that institutions set the possibilities but also the rules and limits of change, inclusive of their own change. Another contribution is the notion that change does not always follow a rationale of expected consequences (March and Olsen 1989). Longitudinal studies of reforms (e.g., Czarniawska 1992) demonstrate that change can follow a logic of appropriateness that provides legitimacy rather than leading to efficacy. When entering change processes, organizations do what they are expected to do rather than what one may think they need to do, an observation that takes us to two of Czarniawska's points of interest: organizational imitation and fashion.

\section{Imitations and Fashions}

"Imitation, claims Tarde, is the main mechanism of sociality, the main mode of binding people (and things) to one another" (Czarniawska 2004a, p. 121). There is sometimes an element of constraint in imitation, but the proportion of constrained to voluntary and unconscious imitations is negligible. Organizations can be forced at times to introduce some forms and practices - because of legal requirements, for example. But in non-totalitarian societies, coercion is rarely the main force behind imitation. Rather, it is norms, especially professional norms, that constitute the key drivers of imitation.

Norms play a critical role, not only because they tell people what to do; norms are key because they are what people "normally" do. "Professional norms exist because professionals willingly imitate one another, not the other way around" (Czarniawska 2004a, p. 121). Specific ways of doing things become norms when more and more people adopt them. And people adopt norms because they alleviate uncertainty and provide the safe guidance of institutions: if more and more do it... Norms even 
legitimate deviance. When an organization - a city, for example - decides "we will not do that," "that" still proceeds in relation to norms.

With imitation as the driving force, fashion assumes a central role for organizational development. Following Tarde, Czarniawska does not see fashion as negative, irrational, and transient, not least in light of the masculine-oriented metaphors like war, sport, and technology, which are used extensively in the social sciences (Czarniawska 2008b). Fashion, she means, is unavoidable and positive. To be in fashion, a great many organizations show an interest in adopting new ideas to appear contemporary and receive legitimacy from their institutional environment. Fashion provides direction. And when the inspiring potential of a fashion weakens, new fashions arise that serve as fresh sources of inspiration

When all or almost all city services are privatized, it becomes impossible to privatize any more. The next step is municipalization or nationalization, unless a completely fresh invention has arrived in the field. Fashion constantly renews itself, but it chooses among the many inventions that are present at a certain time and place. (Czarniawska 2002, p. 135)

While working within the limits of the institution, fashion thus provides opportunities for change. By rejuvenating and thereby updating the existing institutional order, changes may occur, which is why fashion is an integral aspect of the institutional order. As Czarniawska (2009, p. 428) wrote:

Fashion operates at institutional fringes. On the one hand, its variety is limited by the 'iron cage' of existing institutions, which fashion actually reproduces; on the other hand, fashion is engaged in a constant subversion of the existing institutional order, gnawing ant-like at its bars.

Similarly, although fashion seems to sabotage and threaten established institutions, it is also an institutional playing field: new fashions can be tried and disposed of or they can be institutionalized, thus revitalizing the existing institutional order. (p. 428)

The following of fashions is a key element in the pragmatics of organizational change and an explanation for the observation made by institutionalists that managers may be more attracted by institutional conformity than by technical performance. In management as in clothes, art, or intellectual fashions, the trends are set by such fashion leaders as a symbolic metropolis or star companies. Others follow these trends, cheered on by consultants, the professional and general press, researchers, the public, and an entrenched belief among them all in the intrinsic value of newness (Campbell 2015). Think of the companies that have imitated General Motors for decades, designing a divisional structure for themselves or of the company officials who dream of imitating Apple, Google, or Facebook. Imitation provides relentless inspiration for change. But imitation comes with a proven risk of failure. So, based on her observations of city management, Czarniawska (2014b) provides some playful but serious advice to managers interested in reform and change: Learn how to treat fashion from sensible women; check whether it fits your figure and whether you can afford it; and then everything will be okay. 


\section{Translations}

But how do organizations imitate? Through translations answers Czarniawska. Inspired by Serres (1982), Callon (1986), and Latour (1987), she and Guje Sevón (1996) meant that ideas do not spread through diffusion but through translations. And not translations as understood in a strict linguistic sense but as presented in a lesser-known text by Latour (1993, p. 6): "displacement, drift, invention, mediation, creation of a new link that did not exist before and modifies in part the two agents." "Translations" refer to the way organizational actors make theirs the available ideas, whether fashionable or anti-fashionable, or how actors adapt the use of a management model or an artifact to their own premises: understanding, traditions, needs, and means. Translations are active handlings that suppose choices and massive persuasion. And they always entail a transformation of the translated idea or object (Czarniawska 2009, p. 424).

Czarniawska and Sevón (2005) added the finding that ideas travel around the global economy and are always available. Now and then, a particular idea comes into fashion - because it is adopted by some renowned organizational actor, for example - and is translated into local versions by others, reinforcing its status of idea à la mode. The translation starts with the idea being transformed into an object: a buzzword, a model, a PowerPoint presentation, a book, or a pamphlet, for instance. Once transformed into a tangible object, the idea can start travelling and be adopted by actors in other organizations. When translators - planners, managers, coworkers, consultants, but even adversaries - start acting upon the idea, they take various actions to transform the idea into actions that suit their context. A manager in Organization Z, for example, may devise a PowerPoint presentation describing the business potential of digitalization for contemporary organizations. A colleague in Organization A receives a printed version of the presentation, starts talking about how promising is the idea of digitalization, and translates the original presentation into the claim that Organization A needs to change its information system into a more contemporary, efficient, and user-friendly one.

Being materialized and adopted by one organization is a condition for the idea to travel in time and space to other organizations. Yet, the actions taken in the organizations that receive the idea and make it theirs are not sufficient for change to occur. These actions must translate the idea into a day-to-day, repeated, and thus stabilized way of doing things. If the new actions become stabilized to the point of being taken for granted, the new practices originating from the travelling idea have now become institutionalized.

To continue with the hypothetical example of Organization $\mathrm{Z}$ and Organization A, the idea of digitalization is first translated into a budget line and task force for the new information and contacts to acquire new software and hardware, and eventually instruction manuals and course invitations are sent to everybody in the organization. When these "everybodies" start acting upon the idea, repeat their actions, and eventually take them for granted, their translation of the idea has become institutionalized. 
New ideas must fit the existing patterns or categories; they cannot catch on unless they have existed for some time in people's minds. Yet, translations of ideas into actions are always local, and change processes vary from organization to organization. As for fashion, there is a resemblance that bonds the different realization. But each realization is unique, bound to the local contingencies of translations, which is why one can never really foresee the consequences of change - our next point.

\section{Unexpected Consequences}

To reiterate Hirschman's (1991) view, planned change rarely reaches its goals, but unexpected and unplanned effects of changes are nonetheless valuable, except that the people involved may not realize it, focused as they are on their own plans and goals. Barbara Czarniawska has taken Hirschman's view and combined it with Luhmann's (1995) view that systems are geared toward reproducing rather than changing themselves (And if they change by mistake, it is through accidental mutation.). Bringing those two insights together, she has built an analogy inspired by the fictional Baron of Münchhausen, known for recounting enjoyable stories about his impossible achievements, such as riding a cannonball or traveling to the moon. Reusing the slogan of a consulting company, she asked: "Is it possible to lift oneself by the hair?" (Czarniawska 2005a, p. 78).

Obviously not: One cannot lift oneself by one's hair. But knowing that Münchhausen's adventures are impossible does not prevent anyone from listening and enjoying his stories. And knowing about the difficulties of change does not prevent anyone from listening and believing in the potential of change. The point is that people love change but not just any kind of change. As Czarniawska explained in an interview:

My main conclusion concerning organizational change is that it is a total nonsense when everybody's claiming that people do not like change. If people did not like change, we would be all sitting in caves, probably standing in caves. People do not like change that they are forced to by superiors. So, the most positive kind of change, I think, is the spontaneous change that may happen even by mistake or by invention or by somebody doing, like with entrepreneurs, not quite aware of what the institutional order is, and doing some idiotic things that turns out to be very interesting. But then again, like with this sort of unexpected consequences, the point is to observe the spontaneous change and stabilize it if it is positive. (Czarniawska, 2016, On change/interviewer: H. Corvellec, personal communication [unpublished])

In her view, people appreciate the possibility of changing things spontaneously, by mistake, by invention, or by not understanding the rules of the institutional order. The challenge resides in stabilizing it if it is positive. It is through translations that imitation and compliance lead to performative processes of change (Joerges and Czarniawska 1998).

Unintended changes happen all the time, as a new terminology, a new management fashion, or a new technology is introduced into the organization, for example. 
But these beginnings of change do not necessarily develop into actual change. It may be relatively easily for a process of spontaneous change to reach the first stages of translation, when ideas are turned into tangible objects and translated into actions within a particular organizational setting. Seldom are these actions repeated, and rarely do they evolve into taken-for-granted, even normative, behaviors. Rather, the idea will become loosely coupled to the daily life practices taken to accomplish city infrastructure to be build, social security reimbursement to be made, and taxes to be collected. Organizations such as cities, social security authorities, and tax authorities can thereby continue to incorporate new ideas without risking their own survival (Czarniawska 1997).

\section{Action Nets}

Even unintended consequences can prompt change. Combining institutionalism (from which she borrowed the idea that it is possible in every time and place to speak of a prevailing institutional order) and translation theory (from which she borrowed the idea that connecting actions require the translation of different actions into others), Czarniawska (2004d) employed the concept of action nets to capture organizing at an earlier stage, when things still need to be done, long before organizations can prevail themselves of successful stabilizations. Actions nets provide an understanding of change on the making, suggesting that this making consists of weaving or knitting actions, like threads, through series of translations.

The ground of an action net is recursive actions that connect acting parts through translations. Connections between actions can be as varied as the human imagination. They can be a matter of mutual adjustment, such as when a sommelier helps a restaurant guest choose wine. Connections can also rest on the introduction of a new artifact: an identification program that allows people to sign contracts over the internet, for example. Connections can even be established by individual human action, as when volunteers visit lonely elders to keep them company. The point is that neither action nets nor actors precede actions. No one is a born sommelier, internet banker, or Good Samaritan; one becomes so by performing the type of activities institutionally associated with providing advice, bank services, or care. Organizations and organizational identity are born simultaneously and derive from actions of translations that connect. And change occurs when new actions create new translations that create new connections that create new action nets.

The chronology of an action-net perspective is the opposite of the chronology assumed by a conventional network perspective. According to traditional network theory, actors come first, networks second, and actions in the network third. From the action net perspective, actions come first; networks second; and actors third, whether an individual actor, an artifact, or a formal organization. And at any moment, translations draw from and challenge the existing institutional order.

Once the connections between actions have been made and the action net falls into place, the challenge of change is to stabilize these connections and maintain them in good shape (Lindberg and Czarniawska 2006). When relationships among 
actions are not only stabilized but have also reached a normative and cognitive fixity (that is, they can be justified in an appropriate vocabulary and taken for granted), they will become the basis for actors to acquire organizational identity ("She is a specialist of Italian wines.") and allow them to build networks ("No need to look for another internet provider; we can rely on the one we have.") Not all connections between actions will become stable, however, and a researcher's interest in an action net lies in explaining why ongoing processes of organizing practices will or will not build stable relationships (Lindberg and Walter 2013).

Having described how Barbara Czarniawska binds institutionalism, imitation, fashion, translations, unintended consequences, and action net together to explain organizational change, we now turn to her methodological suggestions for studying change.

\section{New Insights: Processual Methodologies}

Czarniawska's theoretical understanding of change as translation provides a valuable insight in the area of change that requires corresponding processual methodological techniques. In this section, we examine her advocacy of three techniques - organizational ethnography, a narrative stance, and shadowing - showing how they amount to a cohesive whole aimed at understanding the vicissitudes of change.

\section{Organizational Ethnographies}

For Czarniawska (2005b), the most reasonable methodology for understanding change processes are ethnographies of change processes. Change processes are good topics for ethnographies:

.. only what moves is visible. Static pictures dull the senses, as the air traffic controllers know all too well. A smoothly run, well-routinized organization does not offer much insight to a researcher. Things go well because they go well; this might be due to successful routines or to a receptive market, and only a change can reveal the makings of success. (Czarniawska and Sevón 1996, p. 1)

Even failed change processes are periods of great interest, when the taken-forgranted practices are destroyed and reconsidered and new ones are eventually constructed. And ethnographies allow for a focus on the way actors envision change in their translations in their specific settings. They also allow the mapping of the erratic character of organizational processes - and beyond. With coeditors O'Doherty and Neyland, in fact, Czarniawska has recently invited potential contributors to a forthcoming special issue in Organizations (O'Doherty et al. 2016). One should aim, they wrote, at surpassing "the traditional anthropological and/or 'Geertzian' approaches still popular in management and organization studies" (described at length in: Czarniawska 2012) and "explore the ways in which the 
arbitrary might become the rule, or the ways in which the traditional dualisms of the social sciences - macro/micro, global/local, structure/agent - become unsettled and redrawn, or even inverted and displaced under the influence of these objects of concern."

Optimally, a researcher interested in writing an ethnology of change should become involved with an organization that plans for a major change and be invited to follow the outcome of the process of change over a specific time. Such an approach creates an opportunity to compare plans with outcomes but also to meet a variety of planners of change, managers executing the plans, or people resisting the change. An obvious risk is to be left to "the poor originality" that appears in management-oriented research when the preconceptions of managers, planners, and opponents are confirmed (Czarniawska 2001, p. 14). This is why she suggests following the way in which actors actually translate ideas about change into actions and solicit their reflections on these actions. Czarniawska's background in psychology had led her to understand that laboratory experiments do not lead far, whereas observations of the field can contribute to an understanding of multiple dimensions of actions and provide insights about the way actors make sense in and of processes.

Organizational ethnography is typically a processual methodology, but changes, too, are processes. Czarniawska's (2002) study of the management of the City of Warsaw took her approximately 14 months. During that time, a new city council was elected, which meant that she lost half of her interlocutors, and the neighboring departments changed as a result of an administrative reform. She became acutely aware of the difficulty of dealing with the fact that change happens in many places at once, in a net of fragmented, multiple contexts, through multitudes of kaleidoscopic movements of organizers who move around quickly and frequently (Czarniawska 2012). But what could be understood as impediments to a study of change (if one considers change to be the neat deed of a community of more or less heroic managers) gave her an opportunity to follow the hesitant and imperfect knitting and unknitting (the gerundive form is essential here) of the action nets that constitute the very process of change.

\section{Narrative Stance}

Among the methodological tools serving a processual stance, Czarniawska has paid special attention to narrative throughout her career (Czarniawska 1997, 1998, 2004c; Czarniawska and Gagliardi 2003). Starting from Barthes' (1966) classic statement that the narratives of the world are numberless, she considers, with Bruner (1986), that narrative is a specific form of knowledge that contrasts to the logico-scientific form of knowledge; with MacIntyre (1981) that conceiving of life as a narrative provides a rich source of insight; and with Fisher (1987) that telling stories to entertain, to teach and to learn, to ask for an interpretation, and to give one is a specific form of social life - a specific form of communication.

On these multiple grounds, Czarniawska (2004c) suggested a comprehensive use of narratives. Watch how the stories are being made, for example, unfolding how 
leaders bring together temporality and causality to produce a plausible plot about the necessary course of a change process. Collect stories everywhere: in strategic documents, the boardroom, comics posted on office doors, or the elevator. Provoke storytelling by asking respondents to give their views of what happened first, second..., last, and why. And when moving from field to desk (Czarniawska 2014a), interpret the stories by asking what people say; analyze the stories, asking how they say it; and deconstruct the stories, asking which perspective are they privileging and which they are silencing. And set narratives together with or against other narratives. It is then time to assemble your own story, and theorizing being plotting (Czarniawska 2013), produce you own theory.

Narratives on, in, from, about, and around organizations allow researchers to trace and explain how organizational processes move from a state of equilibrium to a rupture of this state, and thereby to another state - the definition of a narrative for Greimas and Courtés (1982). A narrative stance provides an alternative way of reading organization theory. Czarniawska (1999) has argued that organization theory is a specific literary genre, in the sense of an institutionalized and recognizable way of writing and structuring texts. Common bargains at airport newsstands are provided by stories of heroic managers who understand before anyone else does where to head their company; fight mean conservatives, adept at the status quo; and steer their company in the right direction.

\section{Shadowing}

Czarniawska (2007) has had particular interest in another processual methodology: shadowing, considering it "the best field technique in management and organization studies" (Czarniawska 2014c).

Shadowing refers to the technique in which the scholar becomes a shadow, looking over the shoulder of someone or something. The situation is that of an observer, an outsider in time, space, and culture in a relationship that involves following someone or something through daily life. It creates a window of observation opportunity that enables the researcher to generate "knowledge about the ways of life" (Czarniawska 2007, p. 17) in a way that includes both humans and things. Looking at what people do creates openings for interviews about what people actually do, in which a number of insightful aspects of work and processes arise.

Shadowing remedies a shortcoming of "traditional anthropology, à la Malinowski: watching native dances during the day and going at five o'clock to the British embassy (Malinowski that is, not the organization scholars)" (Czarniawska 2014c, p. 91). Contemporary organizational actors are all over the place, which makes observation from a static point less and less relevant. The main attraction of shadowing is thus to make it possible to tackle several of the peculiarities of contemporary management and organizing: the coeval and multiple times, the simultaneity of events occurring in various settings, the non-simultaneity of 
experience, and the virtualization of a growing number of practices (Czarniawska 2007). More and more work is done at and through computers, for example, which has the potential of providing fewer insights thereby making observation less rewarding. But when studying the Italian news agency, Czarniawska was simply given a place at a computer with two screens, such as the journalists themselves were using, and although she could not intervene in their work, she could see "the desk" and "the wire" and shadow the news through the production process. When a discussion started in the newsroom concerning a specific news item, she could trace it in the database; so she always (well, almost always) knew what they were talking about (Czarniawska 2012).

Shadowing allows the researcher to capture change in new ways - as it takes place, rather than retrospectively. During the study, the researcher can trace how changers try things, change purposes, and either stick to their plans or adapt themselves to what is happening and what they have learned. Shadowing makes it possible to study the very process of change, providing change with a new perspective. Less importance is paid to a comparison between purposes and effects, and more attention is given to the way unexpected consequences affect the change process.

\section{Legacies and Unfinished Business: Unusual Study Object}

In addition to her theoretical and methodological contributions, Barbara Czarniawska has contributed to an enlarged understanding of change through an influential choice of "unusual" study objects in management and organization studies. Around cities, action nets, and overflows, she has built multidisciplinary research programs at the Gothenburg Research Institute (GRI) that have attracted the attention of many a $\mathrm{PhD}$ student and researchers. This interest in unusual study objects is among her most significant legacies to the field.

In her first research program, Managing Big Cities, she set out to explore the organizing of Rome, Stockholm, and Warsaw. The program expanded to include changes in such infrastructures as railroads (Corvellec 2001), broadband nets (Dobers 2003), air quality measurement systems (Adolfsson 2005), waste collection (Zapata Campos and Zapata 2013), new public management, and urban innovation strategies (Brorström 2015), demonstrating how cities are maintained by keeping themselves in a perpetual state of change. In her second research program, Organizing Action Nets, Czarniawska stressed the need for organization theory to shift from organizations to organizing, from structures to processes, and focused on the becoming of actors rather than their nature. From the recursive ability of technology to both shape its users and to be shaped by its very use (Eriksson-Zetterquist et al. 2009) to knowledge regimes (Rindzevičiūte 2013), through the role of social contexts for the management of risk (Diedrich and Styhre 2012), this program has demonstrated the adequacy of processual concepts for underpinning processual studies of organizing. 
Her third research program, Managing Overflow, refers to the ubiquitous need to manage affluence and surplus, wastefulness and overload. Two volumes (Czarniawska and Löfgren 2013, 2012) have established the theoretical relevance of a concept that questions such notions as equilibrium, balance, or normality and the social and moral orders attached to them.

Many people may associate Barbara Czarniawska with a specific concept: neo-institutionalism, narrative, translations, shadowing, or overflows, for example. What fewer people might have noticed is that these concepts are far from a disparate ensemble. They build a cohesive whole that is open and welcoming to the approaches and concerns of other researchers. In her works, methodological stances dovetail with theoretical notions, to demonstrate that change is never really as expected, but neither is it unrelated to expectations. She shows that although change is forever changing, it shows fascinating similarities across fields, times, and places and that trying to accompany the rich flow of unfolding change may be all that scholars, but also practitioners, can actually do. Her work offers an open cohesiveness that revitalizes "the theory of organizational change, so that it might help us grasp the complexity of organizational life without either reducing it to simplistic models or replacing it with complication of the argument" (Czarniawska and Sevón 1996, p. 8).

\section{References}

Adolfsson, P. (2005). The obelisks of Stockholm. In B. Latour \& P. Weibel (Eds.), Making things public: Atmospheres of democracy (pp. 396-397). London: ZKM/The MIT Press.

Barthes, R. (1966). Introduction à l'analyse structurale des récits. Communication, 8, 7-33.

Berger, P. L., \& Luckmann, T. (1966). The social construction of reality: A treatise in the sociology of knowledge. New York: Doubleday.

Brorström, S. (2015). Implementing innovative ideas in a city: Good solutions on paper but not in practice? International Journal of Public Sector Management, 28(3), 166-180.

Bruner, J. S. (1986). Actual minds, possible worlds. Cambridge, MA: Harvard University Press.

Brunsson, N. (1976). Propensity to change: An empirical study of decisions on reorientations. Göteborg: BAS.

Brunsson, N. (1985). The irrational organization: Irrationality as a basis for organizational action and change. Chichester: Wiley.

Brunsson, N., \& Olsen, J. P. (1990). Makten att reformera. Stockholm: Carlsson.

Brunsson, N., \& Olsen, J. P. (1993). The reforming organization. London: Routledge.

Callon, M. (1986). Some elements of a sociology of translation: Domestication of the scallops and the fishermen of St Brieuc Bay. Sociological Review Monograph, 32, 196-233.

Campbell, C. (2015). The curse of the new: How the accelerating pursuit of the new is driving hyper-consumption. In K. M. Ekström (Ed.), Waste management and sustainable consumption: Reflections on consumer waste (pp. 29-51). Abingdon: Routledge.

Corvellec, H. (2001). Talks on tracks-debating urban infrastructure projects. Studies in Cultures, Organizations and Societies, 7(1), 25-53.

Czarniawska, B. (1992). Styrningens paradoxer: Scener ur den offentliga verksamheten. Stockholm: Norstedts juridikförlag. 
Czarniawska, B. (1997). Narrating the organization: Dramas of institutional identity. Chicago: University of Chicago Press.

Czarniawska, B. (1998). A narrative approach to organization studies. Thousand Oaks: SAGE.

Czarniawska, B. (1999). Writing management: Organization theory as a literary genre. Oxford: Oxford University Press.

Czarniawska, B. (2001). Having hope in paralogy. Human Relations, 54(1), 13-21.

Czarniawska, B. (2002). A tale of three cities: Or the glocalization of city management. Oxford: Oxford University Press.

Czarniawska, B. (2004a). Gabriel Tarde and big city management. Distinktion: Journal of Social Theory, 5(2), 119-133.

Czarniawska, B. (2004b). My mother's daughter. In R. E. Stablein \& P. J. Frost (Eds.), Renewing research practice (pp. 125-136). Stanford: Stanford Business Books.

Czarniawska, B. (2004c). Narratives in social science research. London: SAGE.

Czarniawska, B. (2004d). On time, space, and action nets. Organization, 11(6), 773-791.

Czarniawska, B. (2005a). En teori om organisering. Lund: Studentlitteratur.

Czarniawska, B. (2005b). Fashion in organizing. In B. Czarniawska \& G. Sevón (Eds.), Global ideas: How ideas, objects and practices travel in the global economy (pp. 129-146). Copenhagen: Liber.

Czarniawska, B. (2007). Shadowing and other techniques for doing fieldwork in modern societies. Malmö: Liber.

Czarniawska, B. (2008a). How to misuse institutions and get away with it: Some reflections on institutional theory(ies). In R. Greenwood, C. Oliver, R. Suddaby, \& K. Sahlin (Eds.), The SAGE handbook of organizational institutionalism (pp. 769-782). London: SAGE.

Czarniawska, B. (2008b). A theory of organizing. Cheltenham: Edward Elgar.

Czarniawska, B. (2009). Emerging institutions: Pyramids or anthills? Organization Studies, 30(4), 423-441.

Czarniawska, B. (2010). Going back to go forward: On studying organizing in action nets. In T. Hernes \& S. Maitlis (Eds.), Process, sensemaking, and organizing (pp. 140-160). Oxford: Oxford University Press.

Czarniawska, B. (2012). Organization theory meets anthropology: A story of an encounter. Journal of Business Anthropology, 1(1), 118-140.

Czarniawska, B. (2013). What social science theory is and it is not. In H. Corvellec (Ed.), What is theory? Answers from the social and cultural sciences (pp. 99-118). Stockholm: Liber and CBS Press.

Czarniawska, B. (2014a). Social science research: From field to desk. Los Angeles: SAGE.

Czarniawska, B. (2014b). A theory of organizing (2nd ed.). Cheltenham: Edward Elgar.

Czarniawska, B. (2014c). Why I think shadowing is the best field technique in management and organization studies. Qualitative Research in Organizations and Management: An International Journal, 9(1), 90-93.

Czarniawska, B., \& Gagliardi, P. (2003). Narratives we organize by. Amsterdam: John Benjamins.

Czarniawska, B., \& Löfgren, O. (Eds.). (2012). Managing overflow in affluent societies. London: Routledge.

Czarniawska, B., \& Löfgren, O. (2013). Coping with excess: How organizations, communities and individuals manage overflows. Cheltenham: Edward Elgar publishing.

Czarniawska, B., \& Sevón, G. (1996). Translating organizational change. Berlin: de Gruyter.

Czarniawska, B., \& Sevón, G. (2005). Global ideas: How ideas, objects and practices travel in the global economy. Malmö: Liber.

Diedrich, A., \& Styhre, A. (2012). International expertise and local know-how in the trading zone. Scandinavian Journal of Management, 28(4), 340-351.

Dobers, P. (2003). Image of Stockholm as an IT city: Emerging urban entrepreneurship. In C. Steyaert \& D. Hjorth (Eds.), New movements in entrepreneurship (pp. 200-217). Aldershot: Edward Elgar Publishing. 
Eriksson-Zetterquist, U., Lindberg, K., \& Styhre, A. (2009). When the good times are over: Professionals encountering new technology. Human Relations, 62(8), 1145-1170.

Fisher, W. R. (1987). Human communication as narration: Toward a philosophy of reason, value, and action. Columbia: University of South Carolina Press.

Greenwood, R., Oliver, C., Sahlin, K., \& Suddaby, R. (2008). Introduction. In R. Greenwood, C. Oliver, K. Sahlin, \& R. Suddaby (Eds.), The SAGE handbook of organizational institutionalism (pp. 1-46). London: SAGE.

Greimas, A. J., \& Courtés, J. (1982). Semiotics and language: An analytical dictionary (trans: Crist, L. \& Patte, D.). Bloomington: Indiana University Press.

Hirschman, A. O. (1991). The rhetoric of reaction: Perversity, futility, jeopardy. Cambridge, MA: Belknap Press.

Jepperson, R. L. (1991). Institutions, institutional effects, and institutionalism. In W. W. Powell \& P. J. DiMaggio (Eds.), The new institutionalism in organizational analysis (pp. 143-163). Chicago: The University of Chicago Press.

Joerges, B., \& Czarniawska, B. (1998). The question of technology, or how organizations inscribe the world. Organization Studies, 19(3), 363-385.

Latour, B. (1987). Science in action: How to follow scientists and engineers through society. Cambridge, MA: Harvard University Press.

Latour, B. (1993). Messenger talks. Working paper 9 - Institute of Economic Research, Department of business administration, Lund University.

Latour, B. (1996). Aramis or the love of technology (trans: Porter, C.). Cambridge, MA: Harvard University Press.

Latour, B. (2002). Gabriel Tarde and the end of the social. In P. Joyce (Ed.), The social in question: New bearings in history and the social sciences (pp. 117-132). Abingdon: Routledge.

Lindberg, K., \& Czarniawska, B. (2006). Knotting the action net, or organizing between organizations. Scandinavian Journal of Management, 22(4), 292-306.

Lindberg, K., \& Walter, L. (2013). Objects-in-use and organizing in action nets: A case of an infusion pump. Journal of Management Inquiry, 22(2), 212-227.

Luhmann, N. (1995). Social systems (trans: Bednarz, J. \& Baecker, D.). Stanford: Stanford University Press.

MacIntyre, A. C. (1981). After virtue: A study in moral theory. Notre Dame: University of Notre Dame Press.

March, J. G., \& Olsen, J. P. (1989). Rediscovering institutions: The organizational basis of politics. New York: Free Press.

Meyer, J. W., \& Rowan, B. (1977). Institutionalized organizations: Formal structure as myth and ceremony. American Journal of Sociology, 83(2), 340-363.

O'Doherty, D., Neyland, D., Czarniawska, B. (2016). On the development of ethnographic organization studies: Towards new objects of concern (Call for papers Special Issue of Organization). Organization. Retrieved from http://org.sagepub.com/site/misc/call_for_papers_ formatting trial.xhtml

Powell, W. W., \& DiMaggio, P. J. (1991). The new institutionalism in organizational analysis. Chicago: University of Chicago Press.

Rindzevičiūte, E. (2013). Institutional entrepreneurs of a difficult past: The organisation of knowledge regimes in post-soviet Lithuanian museums. European Studies: A Journal of European Culture, History and Politics, 30(1), 63-95.

Serres, M. (1982). Hermes: Literature, science, philosophy (trans: Harari, J.V. \& Bell, D.F.). Baltimore: Johns Hopkins U.P.

Tomasi di Lampedusa, G. (1960). The leopard (trans: Colquhoun, A.). London: Pantheon.

Weick, K. E. (1979). The social psychology of organizing. New York: McGraw-Hill.

Zapata Campos, M. J., \& Zapata, P. (2013). Switching Managua on! Connecting informal settlements to the formal city through household waste collection. Environment and Urbanization, 25 (1), $1-18$. 


\section{Further Reading}

Czarniawska told us that she considers Writing management: Organization theory as a literary genre (Oxford University Press,1999) to be her best book. Yet we believe that $A$ theory of organizing (Edward Elgar, 2014, second edition) may be a more comprehensive introduction to her ideas and Narrating the organization: Dramas of institutional identity (University of Chicago Press, 1997) her best example of how to combine narrative and institutional theory to address organizational change. A tale of three cities: Or the glocalization of city management (Oxford University Press, 2002) illustrates the relevance of studying unusual empirical objects. Social science research: From field to desk (SAGE, 2014) summarizes over 20 years of teaching processual methodologies; what is more, it is written in an engaging style that appeals to students and seasoned researchers alike. 